\title{
FRAMEWORK OF CONSTRUCTION PROCEDURE MANUAL OF THE PROJECT MANAGEMENT UNIT AND OTHER STAKEHOLDERS IN THE SURABAYA CITY GOVERNMENT
}

\author{
I Nyoman Dita Pahang Putra \\ Department of Civil Engineering, Universitas Pembangunan Nasional Veteran Jawa Timur, \\ Raya Rungkut Madya Street Surabaya, Indonesia \\ Yuni Sari Amalia \\ Airlangga University - Surabaya, Indonesia \\ Gusti Ayu Mayani Kristina Dewi \\ Udayana University - Denpasar, Indonesia
}

\begin{abstract}
The development of comprehensive infrastructure can be passed by accelerating the construction and renovation of city facilities, such as schools, government offices, markets and other facilities. Accelerating the construction of city facilities, such as buildings, requires comprehensive planning and implementation through a wellcoordinated implementation between Contractors and Supervisors. The project to construct a city facility in the form of a building is a relatively complex process because of the many variables and components of work that must be completed properly in accordance with technical and administrative specifications regulated in central and regional regulations. Project success is not only in the mastery of project management but is also influenced by humans as controllers in project management. Therefore, PMU and stakeholders procedure manual are needed, so that the identification of tasks and responsibilities in the planning, implementation and supervision phases of the project can be an important document as a guide in managing the project towards project success. The purpose of this study is to determine the tasks and flow of PMU activities with stakeholders which is explained through the procedure manual. The type of research used is expose facto. Data were obtained and collected using FGDs and analyzed using a qualitative approach. In the PMU procedure manual with stakeholders in the implementation and supervision phases, it can be concluded that the tasks and responsibilities of the Contractor and Supervisor are still more dominant. The PMU carries out assistance in an integrated manner in its implementation and supervision phases so that in this phase it follows the methods and rules that apply and are specified in the project documents. The implementation and supervision PMU conducts intensive
\end{abstract}


assistance and monitoring since the initial conditions of the project begin to be carried out until supervision hand over.

Keywords: procedure manual, task and activity flow.

Cite this Article: I Nyoman Dita Pahang Putra, Yuni Sari Amalia and Gusti Ayu Mayani Kristina Dewi, Framework of Construction Procedure Manual of the Project Management Unit and Other Stakeholders in the Surabaya City Government. International Journal of Advanced Research in Engineering and Technology, 10(6), 2019, pp. 174-182.

http://iaeme.com/Home/issue/IJARET?Volume $=10 \&$ Issue $=6$

\section{INTRODUCTION}

\subsection{Background}

The development of infrastructure in the city of Surabaya is very rapid. This can be seen from the growth of various city facilities. Developments in the infrastructure sector have contributed to the growth of many other activities [1]. The development of comprehensive infrastructure can be passed by accelerating the construction and renovation of city facilities, such as schools, government offices, markets and other facilities.

The construction of facilities in the City of Surabaya, East Java Province of Indonesia, which is an asset of the city government, is carried out by the Office of Public Housing and Settlement Area - Work and Spatial System, the Office of Road Building, the Office of Cooperatives and the Office of Youth and Sports, which are part of the Work Unit Regional Apparatus (WURA). Accelerating the construction of city facilities, such as buildings, requires comprehensive planning and implementation through a well-coordinated implementation between Contractors and Supervisors. The project to construct a city facility in the form of a building is a relatively complex process because of the many variables and components of work that must be completed properly in accordance with technical and administrative specifications regulated in central and regional regulations.

In the planning and implementation of construction projects, a Work Plan and Requirements (WPR) and technical specifications are required, which in the planning process requires indepth assistance and in the implementation and supervision must follow the applicable methods and rules and are stipulated in the project documents. Based on this, it is needed a unit that can provide assistance and monitoring both in the planning and implementation phases. The planning and implementation unit is called the Project Management Unit (PMU). This is in line with the Construction and Building Manual [2] which explains the Project Management Unit, hereinafter referred to as PMU, is a unit that is one of its tasks is to carry out coordination of implementation and compile reports and evaluations of implementation. The existence of PMU is also in line with what is stated in the Project Procedure Manual [3].

\subsection{Infrastructure Development}

The development of infrastructure in Surabaya is very fast with the use of various facilities, requiring inherent coordination between WURAs responsible for urban development, planners, contractors and supervisors in the implementation of their development. Surabaya City Development is divided into 5 areas namely Central Rayon, North Rayon, East Rayon, South Rayon and West Rayon. The division of rayon serves to make coordination and accountability for infrastructure development in Surabaya more persuasive and massive. The division of rayon in the development of the city of Surabaya, also takes into account the very large area of the city of Surabaya which is equal to $350.5 \mathrm{~km}^{2}$ (Figure 1). 
Framework of Construction Procedure Manual of the Project Management Unit and Other Stakeholders in the Surabaya City Government

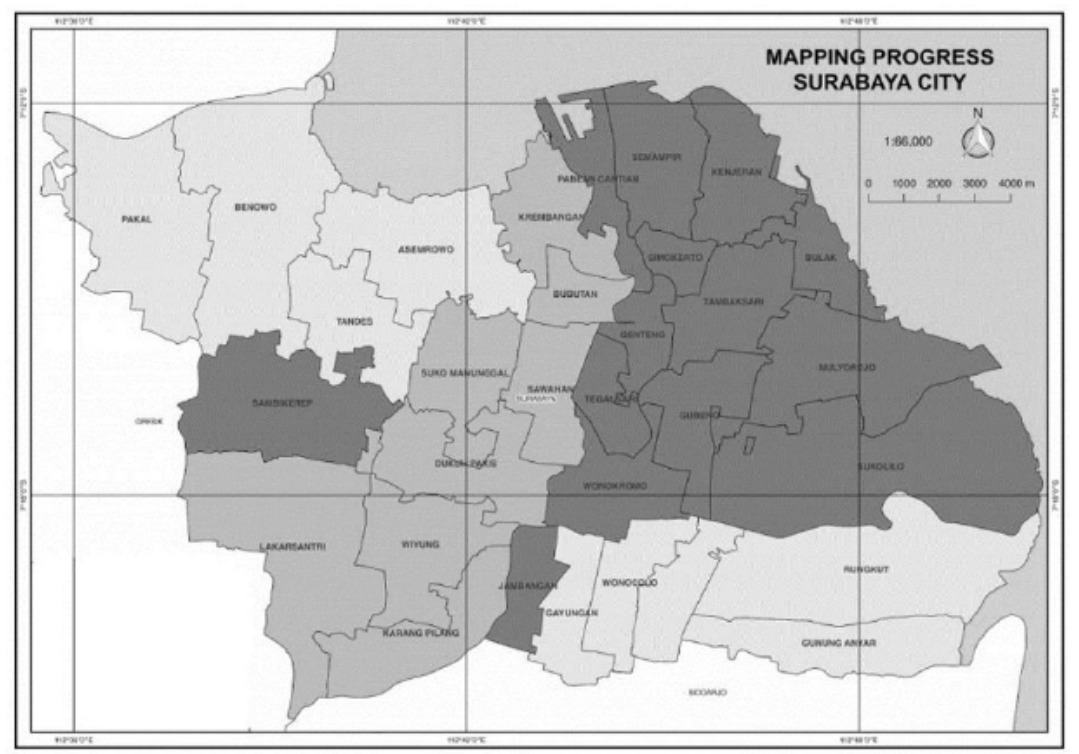

Figure 1. Surabaya City Map

In Figure 2 can be explained based on data from the Central Statistics Agency (CSA) in 2019, Surabaya City is the area with the most population in East Java, reaching 2.89 million people or around $7 \%$ of the total. Malang Regency is the second most populous region, reaching 2.59 million people. The Jember Regency ranks third with a population of 2.44 million.

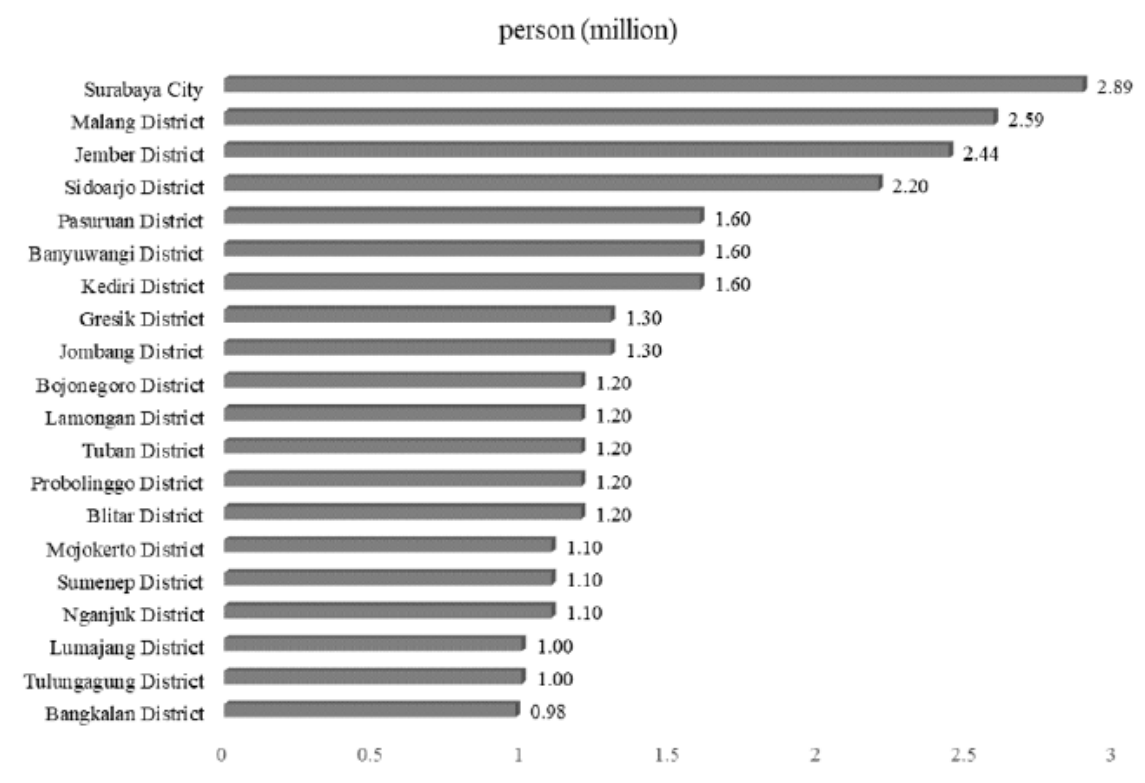

Figure 2. Total Population of the Surabaya City (CSA, 2019)

Based on Figures 1 and 2 above, it is appropriate that the management of infrastructure development in the City of Surabaya requires good coordination between WURA, Planners, Contractors and Supervisors. In the process of planning and implementing construction projects that are so numerous in quantity the project package and still maintaining quality, continuous assistance and monitoring is needed. This is due to the many problems that arise in the project planning and implementation process. This condition is in line with that described by Suraji (2018) [4], in the planning and implementation phase of the project there are several technical problems which become challenges that must be resolved and minimized. In the planning phase namely the emergence of location problems, detailed engineering design (DED), study of the 
foundation and capacity of the planner, in the implementation phase problems arise related to shop drawings, site management, construction methods, contractor and worker capacities, cash flow and as built drawings, and in the supervision phase arises problems related to the capacity of construction management supervisors and consultants as well as the control process in supervision. Based on this explanation, it is necessary to have a PMU for Planning and PMU for Implementation and Supervision as a unit that can conduct monitoring, evaluation and assistance in the planning phase and the implementation and supervision phases. The assignment of tasks between PMU and stakeholders in this case is the WURA, Contractors, Supervisors, Planners and Users elements need to be clearly identified so that project management can be in accordance with the duties of each element, so that project success can be achieved.

Project success is not only in the mastery of project management but is also influenced by humans as controllers in project management [5]. Therefore, PMU and stakeholder procedure manual are needed, so that the identification of tasks and responsibilities in the planning, implementation and supervision phases of the project can be an important document as a guide in project management towards project success. Ryoo (2013) [6] explains that the more projects that involve many contractors and subcontractors, the more difficult it is to conduct monitoring and control, because the management processes and procedures they use are different. Therefore the project procedure manual is intended to enforce policies and be an important part of the success of project management in the construction industry.

\subsection{Area Study and Objectives}

The study area of this study is limited to the Building Division (BD), the Office of Public Housing and Settlement Area - Work and Spatial System in Surabaya City Government as elements of WURA, and procedure manual for identifying PMU performance and tasks with stakeholders are limited to implementation and supervision phases.

The aim of this research is:

- Determine the tasks of PMU Planning and PMU Implementation and Supervision and the tasks of other stakeholders namely BD, Contractor, Supervisor, Planner and User.

- Explain the flow of activities and coordination between PMU and stakeholders.

\subsection{Benefits of Research}

The benefits of this research can be identified the tasks on each BD, PMU Planning and PMU Implementation and Supervision, Contractor, Supervisor, Planner and User and can be understood the flow of activities and coordination between elements, making it easier to evaluate and monitor the tasks of each element.

\section{MATERIALS AND METHODS}

\subsection{Materials}

The type of research used is expost facto. Expost facto is research that aims to find the causes that allow changes in behavior, symptoms or phenomena caused by an event, behaviour or things that cause changes in the independent variables that as a whole have already occurred. The methodological expost research is an experimental research which also tests hypotheses but does not provide certain treatments for some reason because it is not ethical to provide treatment or provide manipulation. Usually for reasons of human ethics or symptoms/events have occurred and want to explore the factors causing it or the things that influence it [7]. Data obtained and collected using focus group discussion (FGD) and analysed using a qualitative approach. 


\subsection{Method of Study}

FGD is a form of data collection activities through group interviews and discussion in groups [8]. The FGD was conducted in 4 sessions where each session was guided by 3 discussion facilitators. The first session was attended by 5 personnel in 1 PMU Implementation and Supervision group and 5 personnel in 1 PMU Planning group. The second session was followed by $10 \mathrm{BD}$ personnel who were divided into 2 groups, each group consisting of 5 BD personnel. The third session was followed by 10 Contractor Personnel divided into 2 groups, 10 Supervisor personal divided into 2 groups and 10 Personal Planners divided into 2 groups. The fourth session was followed by 10 personal users who were divided into 2 groups. Data obtained from the FGD results are used to identify the tasks that are the responsibilities of the BD, PMU Planning and PMU Implementation and Supervision, Contractors, Supervisors, Planners and Users.

The sampling technique used at the FGD stage was purposive sampling with the aim that the personal representatives who took part in the FGD were personal groups who had the authority to set policies and were able to think critically. In addition, the chosen person has more than 10 years experience. Samples that were involved in the FGD are shown in Table 1.

Table 1. FGD Sample

\begin{tabular}{|c|c|c|}
\hline PMU and Stakeholders & $\begin{array}{c}\text { Number of personal } \\
\text { involved }\end{array}$ & $\begin{array}{c}\text { Number of Discussion } \\
\text { Groups }\end{array}$ \\
\hline PMU Implementation and Supervision & 5 & 1 Group \\
\hline PMU Planning & 5 & 1 Group \\
\hline $\mathrm{BD}$ & 10 & 2 Groups \\
\hline Contractor & 10 & 2 Groups \\
\hline Supervisor & 10 & 2 Groups \\
\hline Planner & 10 & 2 Groups \\
\hline User & 10 & 2 Groups \\
\hline Total & 60 & 12 Groups \\
\hline
\end{tabular}

\section{RESULTS AND DISCUSSIONS}

\subsection{Procedure Manual}

Project implementation and supervision in the Building Division (BD), the Office of Public Housing and Settlement Area - Work and Spatial System in Surabaya City Government is the implementation of projects managed by the BD with limited restrictions on WPR and technical specifications, which in the process are carried out in close supervision and in their implementation and supervision must follow the methods and rules that apply and are specified in the project document.

The tasks and responsibilities of PMU and Stakeholders as outlined in the procedure manual in the implementation and supervision phases are as follows:

\section{BD}

Holding a coordination meeting, coordinating pre construction meetings, coordinating the uitzet/joint location inspection, knowing the results of mutual checks (MC)-0 and Shop Drawing (SD), knowing the results of mutual checks (MC) -100 and As Built Drawing (ABD), Review Field Physical Condition 100\%: assistance and control of quantity and quality of MC100 and ABD results, Signing of Minutes of Physical Examination and Provision Hand Over (PHO). 


\section{PMU Implementation and Supervision}

Conduct comprehensive aspects review, coordinate work adjustments (addendum) through mentoring in making technical studies according to the type, quantity, quality of work and time as well as mentoring in calculating and making MC-0 and SD, approving technical studies, MC-0 and SD results, accompanying the process of carrying out activities/work and subactivitie, approving the results of MC-100 and ABD, Field Review of Physical Conditions $100 \%$ through quantity and quality control of MC-100 and ABD results, Signing of Report of Physical Examination and PHO.

\section{Supervisor}

Develop control mechanisms and techniques, coordinate work adjustments (addendum) through assistance in making technical studies according to type and accompany the calculation and making of MC-0 and SD, approve technical studies and calculation and making of MC-0 and SD, approve the quality of materials and work i.e. material approval sheet and mock-up, material quality sheet and material strength test report, making Report of Inspection of the Results of Structural, Architectural and Mechanical Electrical Piping, Control of implementation time and physical progress: on site and workshop control, S curve control and deviation between the time of the plan, proposals and actual implementation, control of network diagrams takes precedence at critical paths, making Daily Reports, making Weekly Reports, making Monthly Reports and documenting work, approving the calculation and making of MC100 and $\mathrm{ABD}$, approving the results of $\mathrm{MC}-100$ and $\mathrm{ABD}$, field review of $100 \%$ physical condition through measurement the quantity and quality of the MC-100 and ABD results, Signing of Report of Physical Examination and PHO.

\section{Contractor}

Implement methods and equipment used as well as scheduling, control adjustments to work (addendum) through making technical studies according to type and making calculations and MC-0 and SD, approving technical studies as well as calculating and making MC-0 and SD, making material quality proposals and work, namely material approval sheet and mock-up, material quality sheet and material strength test report, approve Minutes of Inspection of Electrical, Architectural and Mechanical Piping Work Results, Making S curves and deviations between time of plans, proposals and real implementation, making networks diagrams are preferred on critical paths, approve Daily Reports, approve Weekly Reports and approve Monthly Reports, approve the calculation and making of MC-100 and ABD, field review of physical conditions $100 \%$ through measurement of the quantity and quality of MC-100 and ABD results, News Signing Event Physical Examination and PHO.

\section{User}

Determine the function, capacity and space requirements, make a letter requesting adjustments to the function, capacity and space requirements.

\section{Planner}

Accompanying actively the adjustment of functions, capacities and space requirements, related to the work addendum namely making technical studies according to the type, quantity, quality of work and time, assisting in the calculation and manufacture of MC-0 and SD, approving technical studies as well as calculating and making MC - 0 and SD.

\section{PMU Planning}

Accompanying actively the adjustment of functions, capacities and space requirements, related to the work addendum namely assisting technical studies according to the type, quantity, quality of work and time, assisting in the calculation and manufacture of MC-0 and SD, approving technical studies, results of MC-0 and SD. 
Framework of Construction Procedure Manual of the Project Management Unit and Other Stakeholders in the Surabaya City Government

Based on the explanation above, it can be described procedure manual of tasks and activities the PMU with Stakeholders in the implementation and supervision phases, as visualized in Figure 3.

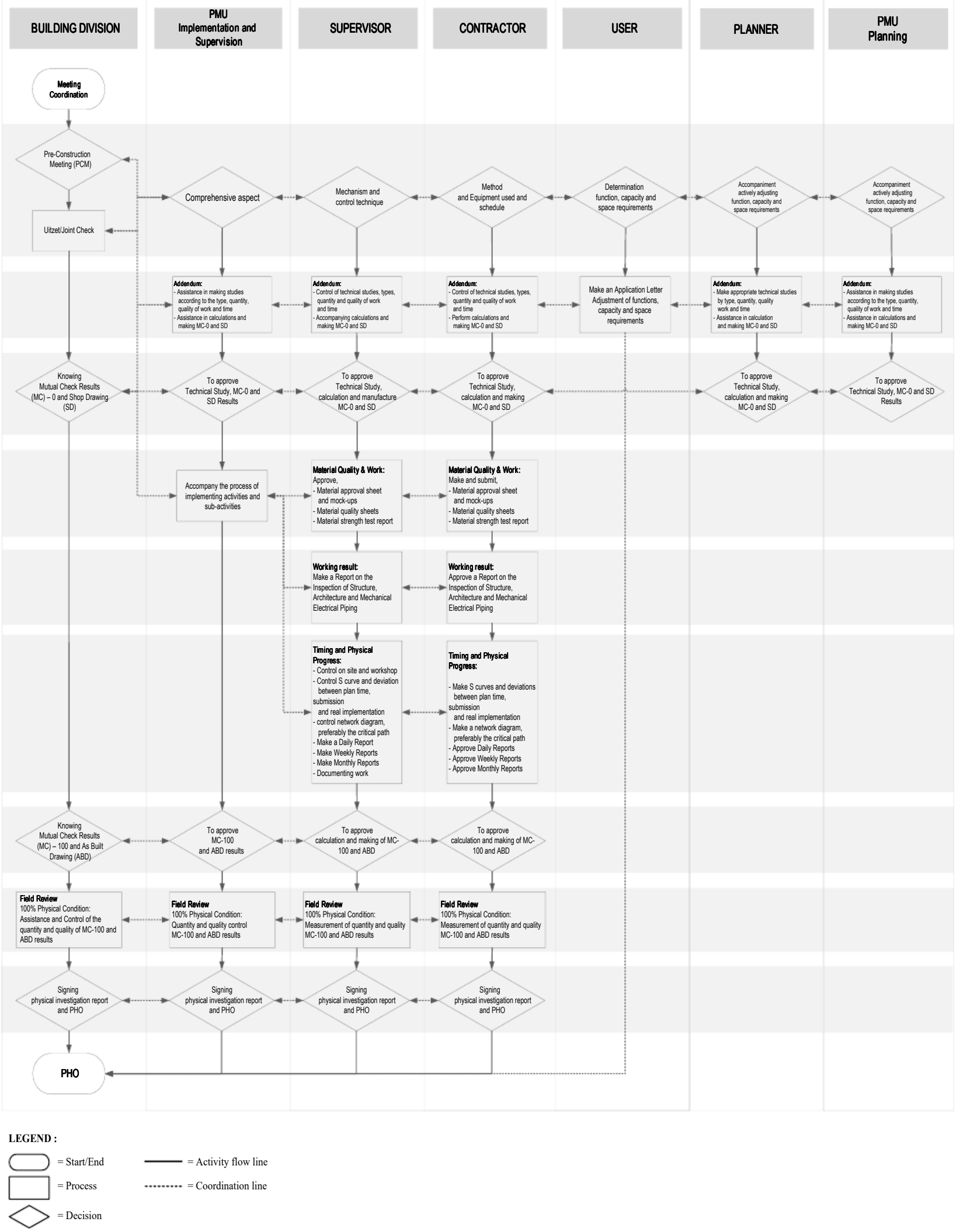

Figure 3. Procedure Manual of the Implementation and Supervision Phase 


\subsection{Discussions}

In Figure 3, explained the procedure manual of tasks and activities the PMU and other Stakeholders in the implementation and supervision phases. In explaining the tasks and activities the PMU and other Stakeholders a more detailed explanation is needed in the details of their tasks and activities, which can be further explained in the contract documents of each element, so that project management can run well and lead to project success. In the follow-up research a PMU procedure manual is needed with stakeholders in the planning phase.

\section{CONCLUSIONS}

In the procedure manual of tasks and activities the PMU and other Stakeholders in the implementation and supervision phases, it can be concluded that the tasks and activities of the Contractor and Supervisor are still more dominant. The PMU carries out assistance in an integrated manner in its implementation and supervision phases so that in this phase it follows the methods and rules that apply and are specified in the project documents. The implementation and supervision PMU conducts intensive assistance and monitoring since the initial conditions of the project begin to be carried out until supervision hand over.

\section{REFERENCES}

[1] Putra, I Nyoman Dita Pahang. (2018). Land Value Estimation Model as Impact of Infrastructure Development in Kaliwates Jember Indonesia. International Journal of Civil Engineering and Technology. Volume 9, Issue 11, November 2018, pp. 1016-1030.

[2] Indonesia Republic Government. (2015). Construction and Building Manual number 01/M/BM/2015. Published by the Regional Roads Development Project (RRDP) Ministry of Public Works Directorate General of Highways of the Republic of Indonesia, pp. 15.

[3] Federation of Bosnia and Herzegovina. (2014). Project Procedurs Manual. Published by Federal Ministry of Agriculture, Water Management and Forestry, Project Management Unit (PMU), pp. 17-18.

[4] Suraji, Akhmad. (2018). Sistem Manajemen Proyek Pembangunan Rusun. Komite Keselamatan Konstruksi Kementerian Pekerjaan Umum dan Perumahan Rakyat Republik Indonesia, pp. 3.

[5] Al-Hajj, Assem and Zraunig, Mario M. (2018). the Impact of Project Management Implementation on the Successful Completion of Projects in Construction. International Journal of Innovation, Management and Technology, Vol. 9, No. 1, February 2018, pp. 2127.

[6] Ryoo, Boong Yeol. (2013). Framework of Construction Procedure Manuals for PMIS Implementation. Journal of Building Construction and Planning Research, 2013, 1, pp. 4553.

[7] Widarto. (2013). Penelitian ExPost Facto. Pelatihan Metodologi Penelitian Pendidikan. Universitas Negeri Yogyakarta, pp. 2.

[8] Indrizal, Edi. (2014). Diskusi Kelompok Terarah - Focus Group Discussion (FGD) (Prinsip-Prinsip dan Langkah Pelaksanaan Lapangan). JANTRO. Jurnal Antropologi: IsuIsu Sosial Budaya. Vol 16, No 1 (June 2014), pp. 75-82.

[9] Yusuf Latief, Akhmad Suraji, Leni Sagita and Rossy Armyn Machfudiyanto (2018), Structural Equation Model Stakeholders in Developing Safety Culture to Increase Safety Performance in Construction Sector, International Journal of Civil Engineering and Technology, 9(6), 2018, pp. 1660-1667 
Framework of Construction Procedure Manual of the Project Management Unit and Other Stakeholders in the Surabaya City Government

[10] Paolo Pietro Biancone, Silvana Secinaro and Alessandra Indelicato (2014), Public Local Group: The Influence of Stakeholders in Consolidated Accounting Process. Empirical Evidence in Italy, International Journal of Management (IJM), Volume 5, Issue 10, October (2014), pp. 115-121.

[11] Anand V Aswale and Abhijit N Bhirud (2018), A Review Paper on "Study of Factors Affecting Labour Productivity in Construction and Study Methods to Improve Labour Productivity in RCC Work. International Journal of Advanced Research in Engineering and Technology, 9(6), 2018, pp 97-103. 